\title{
Félix and the Light-hearted Gay Road Movie: Genre, Families, Fathers and the Decolonization of the Homosexual Self ${ }^{1}$
}

\author{
MURRAY PRATT \\ Never saw the sun shining so bright, never saw things going so right. \\ Blue Skies, Irving Berlin
}

Released in 1999, Drôle de Félix, the second feature by directors Jacques Martineau and Olivier Ducastel, is considered quirky, light-weight - "refreshing" according to the tag on the appropriately-named Peccadillo Pictures DVD cover. The original trailer, set to the languid soft-jazz score of "Tout doucement" which also accompanies the film's opening titles, collates randomly culled snippets under the headings "drôle de mec", "drôle d'amitié", "drôle de rencontres", "drôle de voyage", "drôle d'amour", "drôle d'histoire" and finally "drôle de Félix". You get the picture. It's a funny kind of a film. Maybe a little "funny peculiar", and maybe also a bit "funny ha-ha". According to Chris Gallant of Gay Times, in a review reproduced on the DVD cover, Drôle de Félix is "moving, funny, sexy, romantic, ultimately compelling and utterly irresistible".

The plot structure of Drôle de Félix is uncomplicated, a journey by the main protagonist from Dieppe to Marseille in search of his father whom he has never known. Arranging to meet with his boyfriend at his destination, he hits the road, encountering various characters along the way and forming a relation with each. These characters, introduced in terms of imagined familial links (respectively "mon petit-frère", "ma grand-mère", "mon cousin", "ma sœur" and "mon père"), each share a little wisdom (and spread a little happiness) with Félix before he heads off on his way. Between these vignettes, there is the recurrent and predominant image of the film, as featured in marketing campaigns, of Félix by the roadside, hitching lifts, and despite a looming dilemma about whether to inform the police of a racist

\footnotetext{
' Thanks to Paul Allatson, Catriona Elder, Angela Giovanangeli, Lawrence Schehr and Lyn Shoemark for their generous and informed comments and suggestions on drafts of this paper. Versions of the paper were given at the University of Queensland (ASFS Conference, July 2003) and the University of Nottingham Trent (French Staff Seminar, November 2003) - thanks to all those who contributed to the discussions.
} 
assault witnessed in Rouen towards the start of his journey, seemingly without a care in the world. This carefreeness colours the palette of most critical responses, from formal media to the more immediate reactions of amateur internet reviewers. In the words of Time Out's reviewer, Tom Charity, "Watching Sami Bouajila walk through the countryside, singing to himself, dancing a little ... it's a simple reminder that it's good to be alive".' Chris Gallant praises the film for "avoiding all the clichés of the gay feel-good movie", yet describes how its charm, comfort and "pervasive

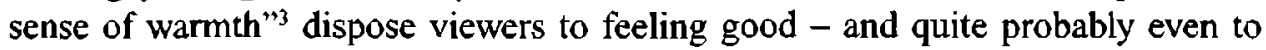
singing if they're glad to be gay. ${ }^{4}$

Two common and related threads emerge from the remarks made. Firstly, the film is considered as essentially something to be enjoyed. While it touches on darker themes, it is reconstructed as a breezy and pleasurable, if quirky, road movie with no serious axes to grind, "low key and unpretentious" in the words of Gallant's more formal review, echoed by amateur responses. Secondly, Drôle de Félix is perceived as a movie where the main character's homosexuality and HIV-status are incidental. Commenting on the duplicity of a phrase such as "happens to be gay" when used by Miramax in marketing The Talented Mr. Ripley, one reviewer claims that the epithet is better applied to Drôle de Félix, which "would probably have worked just as well - and surely played out almost the same, if Felix were heterosexual". ${ }^{5}$ Picking up on the film's normalization of homosexuality and AIDS, reviewers are keen to celebrate a portrayal of an autonomous and relatively empowered gay man living with HIV, whose personality is informed, rather than determined, by his sexuality and immune status. Their reading is one that largely corresponds to contemporary French social discourse that positions lesbian and gay identity according to the right to "indifference" as opposed to more communitarian demands for differentiation, and at the same time, reflects cultural shifts in thinking about AIDS as a more manageable condition as a result of medical advances.

However, the debate occluded by reviewers' insistence on the movie's "lightheartedness" is effectively a far-reaching one about identity, about the extent to which unproblematic and unquestioned belonging in a national context can be extended to society's others. The consensus is that an over-emphasis on those marginalizing characteristics of Félix's identitarian profile - gay, HIV-positive, beur - would detract from the full enjoyment of the film and in particular, relegate it from its

\footnotetext{
${ }^{2}$ Quoted on DVD cover, "Drôle de Félix, a film by Jacques Martineau \& Olivier Ducastel", Peccadillo Pictures, PPDVD006.

${ }^{3}$ Quoted on DVD cover.

- The DVD version released in France by Arte goes further, marketing the film, in terms perhaps better suited to a brand of mineral water, as "Un road movie léger et pétillant disponible".

${ }^{s}$ Lodger, Filethirteen.com, http://www.filethirteen.com/reviews/adventuresfelix/adventures felix.htm, accessed 4 January 2004.
} 
potential mass appeal (a film for all the family?) to a place on the sidelines. At a time when France is simultaneously interrogating and reaffirming its national identity as secular and Republican, such debates, especially around ethnicity and belonging, are familiar to scholars working in the context of post-colonial cultures, as is the extent to which they are often withdrawn from the national agenda. In this context, Alec Hargreaves and Mark McKinney ask "How far do post-colonial cultures stand as part of, or apart from, the dominant elements in the cultural space bounded by the territorial limits of France?" Their answer, drawing on Deleuze and Guattari, calls for a fuller understanding of the extent to which our identities, "whether as producers, consumers or intermediaries", can be best understood according to frameworks that challenge assumptions of the mono-cultural. "Minorities within a given topographical space", they write, "may seek to deterritorialize [the] dominant paradigms [of physical contiguity] by working within cultural circuits that cut across its boundaries". 'Subsequently, identities emerge that account for the complexity of communities, opening up and renewing what national belonging might mean. Looking further into the process of normalizing Drôle de Félix as light-hearted, this paper argues that the protagonist's journey across the boundaries of gender, sexuality and the family effects a similar, and equally important, work of deterritorialization, or decolonization. In the process, the vectors and contours of his mapping of the nation, in addition to amounting to an enjoyable film, depict a work of the self that constructs, deconstructs and reconstructs monolithic understandings of how French national identity is sexualized.

\section{The genre}

Taken together, the themes of light-heartedness and normalization could be seen to evoke the genre of affirmation cinema - old hat for gay movies, but relatively new ground in French AIDS movies, which had previously tended to depict people living with AIDS or HIV in terms of deteriorating health, moral dilemmas and personal or family tragedies. Instead the film is seen as advocating a "positive image" approach to HIV and AIDS, one that the filmmakers, as much as its viewers. were keen to attain. As Olivier Ducastel comments, the aim was to portray someone living with HIV in an optimistic light.

\footnotetext{
"They say it's got to mean something," complains Ducastel, of the French film community's need to deal with AIDS as a metaphor for decay and sickness in society (amongst other things). "And we say, no it doesn't mean anything. It's a fact. It's the way he is." ${ }^{.8}$
}

\footnotetext{
'Alec Hargreaves and Mark McKinney, "Introduction: The Post-Colonial Problematic in France", in Alec Hargreaves and Mark McKinney (eds), Post-Colonial Cultures in France (London: Roulledge, 1997), pp. 3-25 (p.11).

${ }^{7}$ Hargreaves and McKinney, p. 11.

"Quoted in David Collins, "Ze French; she is a funny race. Film Review, Is Funny Felix a
} 
Félix's days have their routines. One is his addiction to the hyper-sensational television soap opera he watches religiously, but that we only experience vicariously through his facial expressions. Another is taking combination therapy drugs at regular times throughout the day. Sometimes he does both at the same time, washing down the pills with gulps of bottled water between one melodrama and the next. In the internal logic proposed by the film, to ask what these routines "are supposed to mean" would be beside the point. Despite being HIV positive, he is simply there.

As posited by Richard Dyer, affirmation cinema can be defined in terms of "thereness, insisting on the fact of our existence; goodness, asserting our worth and that of our life-styles; and realness, showing what we were in fact like". 9 Félix's journey, in the succession of centring moments that put him at one with the physical and familial environments he traverses, becomes an almost contemplative series of moments of being there. Correspondingly, the "thereness" of his homosexuality and HIV status, however incidental, is nonetheless established from the outset through a series of cameos showing him smooching with Daniel in a restaurant, and visiting a clinic to get his prescription of Combivir before setting off. Equally it would be hard to begrudge the film's essential good will, crystallizing with each new friendship made, and reaching a crescendo in the heady reunion with Daniel on board a ferry bound for Corsica. Conflicts are dissolved, if not fully resolved, as with Félix's struggle to resist the advances of Jules, "le petit frère", which becomes a lesson in how to handle rejection. Overall, Drôle de Félix could be seen as typifying Dyer's description of "goodness" in affirmation cinema as a combination of "happy endings, smiling faces, the repetition of the life story as success, avoidance of narratives of intra-gay/lesbian conflict or internalized homophobia". ${ }^{10}$

The questions begged of a film released in fin de millénaire France, however, tend to cluster around the "realness" of its representation. In his biographical account of Act Up Paris, Didier Lestrade describes 1999 as the year when, in the eyes of the French media, the war against AIDS became something to commemorate rather than fight, and unsafe sex a lifestyle choice. ${ }^{11}$ It would therefore be quite legitimate to ask whether Martineau and Ducastel could not have found more engaged ways to depict HIV, and given a different ring to what it might mean to accentuate the positive. Lestrade encapsulates national thinking about the epidemic at the end of the twentieth century in the following terms:

Il n'y a pas une seule personne, dans la société française, qui soutienne la capote. Plus personne ne raconte aujourd'hui ce qu'est le sida. Pas un seul média, depuis trois ans, n'a ramené les choses à leur vraie dimension

metaphoric guy?", Xtra.ca, http://www.xtra.ca/site/toronto2/arch/body580.shtm, 29 June 2000, accessed 4 January 2004.

${ }^{9}$ Richard Dyer, Now You See It: Studies on Lesbian and Gay Film (London and New York: Routledge, 1990), p. 274.

${ }^{10}$ Dyer, p. 274.

" Didier Lestrade, Acr Up. Une Histoire (Paris: Denoël "Impacts", 2000), pp. 422-423. 
[...] Nous sommes les survivants d'une guerre et nous avons un jour pour commémorer tout ça: le ler décembre. Mais la blague c'est que personne n'y va. ${ }^{12}$

In this light, and given the contemporary slide away from safer sex practices in France, as throughout the Anglophone world, an expectation that a film depicting HIV and homosexuality might address some of these issues - in other words try to do a bit more of the meaning thing and a bit less of the warm-heartedness - would not be unrealistic. However, in contrast with a film such as Cyril Collard's Les Nuits fauves, released at the beginning of the 1990 s, and itself already criticized by Act Up Paris for its overly individualistic focus on AIDS, Drôle de Félix routinely deproblematizes Felix's status as HIV-positive, reduced to the rigours of pillpopping. Collard's film, however much characterized by denial or romanticization of the answers it gives, nonetheless works through difficult and often graphic questions about responsibility and safer sex. By comparison, Félix's solitary sexual escapade, with his pseudo-cousin, is only sketched, framed as bucolic idyll, as the narrative segues from some impassioned fumbling during hill-top kite-flying to the protagonists' emergence, naked and post-coital, from the bushes. Risk, responsibility and negotiation are metonymized away from safer sex towards issues about how best to respect the countryside in disposing of the condom, or deal with the nettle rash Félix has suffered in the process (they eventually favour shallot vinegar over the cousin's urine). At the same time, overt discussion of the physical or psychological processes of coping with HIV and AIDS, even at an individual level, appear to be entirely absent from the diegesis, never mind any consideration of the political or social situation. Félix, for instance, in the plenitude of his "thereness", in his untrammelled "goodness", appears untroubled by the kinds of radical selfotherness, or "im-pertinence" often evoked by critics as indicative of the ways in which HIV impacts torturously on identity. ${ }^{13}$ Reduced to the dimensions of a selfmeasuring pill-box, Félix's experience of AIDS in this film is shrunk, on one level, to little more than the necessity for a nifty gadget, a representation as troubling as the erasure of the epidemic from national consciousness outlined by Lestrade.

Equally, issues around Félix's homosexuality receive a deal of airbrushing as the film contrives a series of encounters with characters largely devoid of homophobic or racist sentiment. Two of his new family members are themselves gay, knowledge that circulates here by osmosis rather than dialogue, while two more seem unaware of Félix's sexuality, puzzlingly so in the case of the "sceur" with whom he shares a double bed but who finds it quite natural to spend the night telling him ghost stories, with no questions asked. The fifth is the "grand-mère", whose refusal to believe that someone like Félix could be a "pédé" marks her

\footnotetext{
${ }^{12}$ Lestrade, p. 423.

${ }^{13}$ See for example Alexander Garcia Düttman, At Odds with AIDS (Stanford: Stanford University Press, 1996).
} 
as simply out of touch with the Republican recuperation of sexual difference as "indifférence" characteristic of post-Mittérand France, rather than as vindictive.

And yet, the radical normalization of a gay, Beur, HIV-positive protagonist, despite its failure to engage fully with many of the everyday realities of living with AIDS, would nonetheless conform to the political project of affirmation cinema; not least through its inversion of the powerful discursive logic that positions the white male body as the unacknowledged locus of centrality and entitlement. As Dyer points out, this genre has a tendency to collapse under internal contradictions, with "realness", if taken to accommodate the "usual ragbag of human iniquities"14 and the constructedness of social realities, often compromised to a greater or lesser degree in pursuit of the most immanent "thereness" or purest "goodness". The film's directors, reviewers, and common or garden viewers, then, in almost complete agreement about the pointlessness of looking for meaning in a light-hearted gay movie, are simply responding appropriately to generic edicts, according to which social or cultural realities are, at best, of secondary concern. In a sense, of course, this reading is perfectly adequate - if Martineau and Ducastel want to make a movie about a guy hitching through France and stopping to fly his rainbow kite now and then en route, and enough people want to watch, distribute and buy it, then why ask for a film depicting illness and hate? And yet, still there's something a little funny about Félix. His is a narrative peregrination, after all, that is set in motion and propelled by a nexus of issues about relationality and community in contemporary France - the quest for the father, the construction of a viable pretended family, the notion of temporary fugue enabled by his recent unemployment, the struggle with a guilty conscience from not divulging information to the police - however much the mise-en-scène would like to wish away their identitarian dimensions.

An alternative approach to the meaningfulness or otherwise of Drôle de Félix, that builds upon rather than contests the sense of enjoyment and delight with which the film has been received, is to consider it in terms of another generic code that it evokes, that of the road movie. In the introduction to their comprehensive collection of essays on the genre, ${ }^{15}$ Steven Cohan and Ina Rae Hark widen out definitions of the road movie beyond the ahistorical perspectives to which it had hitherto often been confined. Recognizing Hollywood's democratization of the genre in films that move beyond the Easy Rider paradigm of straight male buddies on a bike, they consider road movies as a vehicle for discovering or contesting, rather than confirming perspectives. Taking their cue from Thelma's rhetorical question "The law is some tricky shit, isn't it?", ${ }^{6}$ Cohan and Hark consider road movies as films that can "look at the consequences of adhering to or opposing laws, of freeing oneself from or seeking to rejoin the wider community". "If the displaced Others

\footnotetext{
${ }^{14}$ Dyer, p. 274.

${ }^{13}$ Steven Cohan and Ina Rae Hark, The Road Movie Book (New York: Routledge, 1997).

${ }^{16}$ Thelma \& Louise, dir. Ridley Scott (1991). $\quad{ }^{17}$ Cohan and Hark, p. 12.
} 


\section{Murray Pratt}

of the frontier are conventionally disregarded in the self-fashioning trajectories of dominant identities, Cohen and Hark consider the genre "a productive ground for exploring issues of nationhood, economics, sexuality, gender, class and race".18

Essays in the collection that explore the revitalization of the road movie as it accommodates marginalized identities - "any women at all, gays, and people of color" 19 - do so in terms that strike a chord with dominant perceptions of Drôle de Félix. Sharon Willis, considering movies where the protagonists are black or Latino, focuses on two films which she sees as "shaped somewhat comedically" and which "resemble fairy tales" in their bid to "dream a different community". 20 "Because these films present themselves as fairy tales, even as fables", she argues, "we cannot hold them to the grounds of plausibility or verisimilitude that often anchor dramatic fictions. Instead, we have to read the collective wishes that they deploy and reinvest in order to understand the stories of community they offer in relation to our contemporary social context".21 Likewise, in an essay drawing on the structuring tropes of "home" and "away", Pamela Robertson contends that The Adventures of Priscilla, Queen of the Desert, despite the exclusionary circumscription of belonging at its heart, is read as a trip towards the reaffirmation of the values of an alternative community, since "as in that other $\mathrm{Oz}$, the discovery that 'there's no place like home' takes place only through leaving that home and journeying to a parallel universe". ${ }^{22}$ Katie Mills's discussion of The Living End, ${ }^{23}$ a very different kind of AIDS road movie, emphasizes the genre's utopic power, seeing the motif of the road as one that "symbolizes the movement of gay bodies not only through the landscape, but especially metaphorically forwards into the future when there might be a cure for the disease"24 and structuring the film as "a generous, impassioned plea for a continuation of love, desire - and cinema - in spite of the social problems which plague us at the end of the century". ${ }^{25}$

Many of these thematics, in particular the sense of a temporary fugue during which the values of "home" - in Félix's case, his bond with his lover Daniel - become reimagined and the sense of an unreality permeating the "away", constructed through wish-fulfilment and the dreamscape in opposition to more everyday processes of marginalization and negation, provide useful leverage on the ways in which Drôle de Félix might begin to mean, or according to which the film's projection of carefree easiness might be situated. However, while Félix shares the "questing belief in

\footnotetext{
${ }^{18}$ Cohan and Hark, p. 12.

${ }^{19}$ Sharon Willis, "Race on the Road. Crossover Dreams", in Cohan and Hark, pp. 287-306 (p. 287).

${ }^{20}$ Willis, p. $304 . \quad 21$ Willis, p. 288.

22 Pamela Robertson, "Home and Away. Friends of Dorothy on the Road to Oz", in Cohan and Hark, pp. 271-286 (p. 283).

${ }^{23}$ Katie Mills, "Revitalizing the Road Genre. The Living End as an AIDS Road Film", in Cohan and Hark, pp. 307-329.

${ }^{24}$ Mills, p. 325.
} 
happiness"26 that propels many of the protagonists of queer road movies, he also seems to differ markedly from them in one key respect. Queer films such as $M y$ Own Private Idaho, according to Robert Lang, are motivated by a need to become a desiring body outside "the spaces of home and family", and in particular, avoid the closure of the "(hetero)patriarchal narrative driven by the conjugal imperative". ${ }^{27} \mathrm{By}$ contrast, Félix is, at least metadiegetically, embraced within the confines of family at every turn, as he heads towards the fulsome finale of his reunion with Daniel. All would seem to suggest, once again, that rather than sharing an affinity with the "disorienting and disturbing" interrogation of the family found in queer cinema, perhaps Drôle de Félix might more pertinently be considered as a post-PACS gay road movie celebrating monogamous and regulated non-desire.

\section{The family}

The element that jars most with the lightheartedness that characterizes most of the film is Félix's role as witness to a murder - specifically, a murder marked diegetically as a racist crime. The incident occurs, with uncharacteristic acceleration, towards the beginning of his journey, with Félix attempting first to intervene, before himself being chased. He then tries to get help from a café owner who turns out to be complicit with the aggressors, and later presents himself at a police station, but changes his mind and walks out. Félix's failure to act then comes back to haunt him later in the film, in conversations with both the "grand-mère" and the "sœur", herself a police officer, and with whom he is eventually able to articulate the reasons for his inaction. "J'avais peur de tout le monde", he tells her, "de ces mecs, des flics, de tous". As an Arab, he points out, there was no way for him to imagine himself explaining the murder to the police. Experimentation with the limits of crime and legality are common tropes within the road movie genre, but with Drôle de Félix, the protagonist is presented less as a fugitive than as someone whose alienation from the institutions of justice prevents him from fully dispensing his civic duty. Although complicated somewhat by the small matter of a car with a baby in the back seat which he steals to impress "le petit frère" (they return the baby), Félix's dilemma is principally one that raises questions about the notion of responsible citizenship within a national space where institutionalized racism makes a sham of the country's pretensions to Republican "égalité". Reflected in his determination to avoid passing through the far right strongholds of Orange and Vitrolles, and to steer clear of big cities, his journey provides both a reminder of the social realities of late twentieth-century France - in the inclusion of the murder in Roven - and goes on to enact an alternative mapping of a France where racism does not have a place.

\footnotetext{
${ }^{25}$ Mills, p. 326.

26 Robert Lang, "My Own Private Idaho and the New Queer Road Movies", in Cohan and Hark, pp. 330-348 (p. 345).

${ }^{27}$ Lang, p. 344.
} 


\section{Murray Pratt}

Likewise, the substintion of the family, which he reconfigures from those he meets on his trip, could be considered as a further reflection of the escapist tendencies of the alternative road movie, according to which the foundational importance of the biologically determined social unit is reinvented by Félix in relatively unproblematic ways - as an attractive but disposable counterpart to, or escape from, the heteronormative injunctions of "family values" from which homosexuality, through its construction as "inconsequential" is excluded ${ }^{28}$ On one level, then, there is scope for considering Félix's adventures as a gay equivalent of playing "away" from "home", a belated discovery of the dubious joys of familiality, and in particular the ardours of parenting, from which his sexuality excludes him. His interrogation, however temporary, of the domestic idyll he shares with Daniel (through the search for his father as representative of the real family he lacks, a quest about which his partner has doubts from the outset), fails to equip Félix with any answers he did not already have. Learning from the assorted fruitloops he meets on the road that any sense of family is always already fragile, or else what you make it, he can sail off into the sunset swathed in the warm glow of his own variety of homeliness.

In contrast with the queer road movie, which "eschews the 'happy ending' of Hollywood cinema, a tacked-on coda that at best is ironic and at worst a reinstatement of the repressive structures that the protagonist(s) sought to escape", ${ }^{29}$ Drôle de Félix, a film with a happy ending, beginning and middle, could be considered as more of a gay B-road movie where the affirmation of the contented homosexual couple transcends all obstacles. However, at a time when France - via national debates on the PACS legislation - was engaged in often bitter debate about social organization and the couple, this would be too easy an accommodation of Félix's reconstitution of the family.

The process of finding a family is not uncontested, as the characters Félix meets each resist, in various ways, the roles designated by the subtitles, with Jules, for example, becoming insulted when Félix reveals the film's paratextual agenda overtly by calling him his little brother. A sense of the journey as a work of building a viable community is also undercut by the episodicity of Félix's family encounters, as, despite his preference for "au revoir" over "adieu", the alternative family he meets refuses to coalesce as a stable or lasting unit. Yet, rather than contrasting with any normative sense of perdurability, the affective universe (faintly reminiscent of the communities of cruising in Renaud Camus's Tricks) ${ }^{30}$ which structures Félix's adventures as sequential emerges as equally constitutive of the parallel world he traverses. The traditional family unit is repeatedly interrogated, having been usurped

\footnotetext{
${ }^{2.8}$ For a theoretical discussion of how inconsequentiality operates as a form of heteronormativism see Annamarie Jagose, Inconsequence: Lesbian Representation and the Logic of Sexual Sequence (Ithaca: Cornell University Press, 2002).

${ }^{29}$ Lang, p. 342.

${ }^{30}$ Renaud Camus, Tricks (Paris: P.O.L., 1988).
} 
by the kind of chaotic arrangements concerning "papas" and "demi-papas" that confuses the youngest child of his putative sister, who maintains amicable relations with the three different fathers of her children. Félix's assumptions that they have a father, rather than fathers, is shown as erroneous, an over-simplification of the diversities and difficulties of navigating parenthood within a heterosexual context: the act of dropping off "les enfants du Rhône et de la Nationale 7" draws out his anticipated single detour to three, in order to accommodate the grammatical $z$-bend by which "leur père" has " $s$ " at the end of each word, and "habite" is actually "zhabitent". What Félix learns from his new family, in the shape of the story of the "grand-mère" and her loveless marriage, or in the autocritique of his capacities which has lead the "père" to detach himself from his entourage, is that fragmentation and loss, substitution and recombination are as much at work within the structures of heteronormativity as they are the felt effects of its injunctions to homosexuality. By the same token, the homonormative terrain that the easy-going cinematic of Drôle de Félix celebrates can, itself, be seen as shot through with the self-shattering effects and reconstructive responses of all normativizing authority.

\section{The Father (or not, as the case may be)}

The landscape of France that Félix traverses contours familiality as a kind of familiarity, a recognition of dysfunctionality, interdependence and getting by as the shared national commonalities that structure Republicanism. Yet, although paying heed to the values of liberty, fraternity and equality, its overt celebration of civic communion irrespective of racial and sexual difference, set to Cheb Mami's soaring and wonderfully ambivalent Rai soundtrack of personal liberation, can also be read as one that contests national scripts, in particular those that seek to uphold the values of patriarchal authority.

For, as much as the film investigates the extent to which familiality structures Félix's identity, his journey is also one that opens up territory for contesting the ground on which both the shape and the predominance of family can be understood. Just as the vignettes defuse the Otherness of those he meets into alternative kinship relations, so too do the interpellations of those he meets reconfigure Félix's identity in unexpected ways. In turn, therefore, he is asked to embody the roles of big brother, grandson, cousin, brother and son in response to the needs of his extended family, and much of the quirkiness of these encounters arises precisely from the departures from role, those excessive expectations which they bring to the encounters as part and parcel of their own quests and trajectories. Confronted with a little brother spoiling for a father figure, a grandmother who observes his nude body, a sister who really needs a childminder, and a cousin ripe for querying the bounds of incest, the journey could hardly be said to be non-challenging. In this sense, the pretended family constructed by Drôle de Félix, rather than unproblematically substituting the normative patriarchal model, can be thought of as reinventing the possibilities of kinship beyond the decrees of the authoritarian paradigm. 


\section{Murray Pratt}

Indeed, the kinds of co-dependent meanings that accrue to each of the relations he builds might be read as a challenge to the primacy of the paternal law, one that asks fundamental questions about the extent to which processes of disciplinarity and social intervention are built into Lacan's formulation of the sexualization of the subject. Specifically, his quest to meet his father, the overt motivation for Félix's trip, can be understood in terms of an exploration of the possibilities for socialization beyond the constraints of Edipalization and the edicts of "the Name of the Father" that found the Lacanian Symbolic order. Didier Eribon, in Une morale $d u$ minoritaire, raises precisely these issues in his analysis of the imbrication of the notion of real, biological fatherhood in what masquerades as apersonal psychic structuration. ${ }^{31}$ For Eribon, the Lacanian conception of homosexuality as a perverse object choice, brought about by the dilution of the authority of the father, can be read largely in the light of a homophobic and sexist defence of the existing order. While Lacan is at pains to construct the paternal function as a "loi qui précède la culture et l'histoire, et n'est done pas accessible au changement". ${ }^{2}$ for Eribon this move is little more than a "structural ruse", since the figure of the real father reappears time and again as pivotal in the enforcement of the child's proper place in the symbolic order, as the agent that determines her or his access to the metaphoric chain of signification ensuring normative functioning. Lacan's construction of this place in contradistinction to the anomaly of homosexuality, for Eribon, offers a reactionary response to the central problem of "comment devenir père" by evoking exemplary masculinity and heterosexuality as the sole defences against the fantasmatical fear of social utopias where straight male power might be contestable.

Félix's pretended family, unruly, random and radically unhierarchised, calls to mind the kind of revolutionary processes of alternative socialization, the women's movement, May 1968, against which Lacan, according to Eribon's re-reading, feels obliged to raise the drawbridge. True to the form of the structural ruse, a strictly Lacanian reading of the film, one that would write off his adventures as precisely meaningless, would emphasize the extent to which, for Félix, "[t]he missing Nameof-the-Father leaves a hole in [his] symbolic universe". ${ }^{33}$ Lacking instruction in the paternal law, the key to the responsibilities of the res publica, Fellix's fruitless encounters might be reduced to the delusionality of the Imaginary order, repeated and futile exercises in narcissism with no issue. Yet this would be beside several points, not least the extent to which, throughout the film, Sami Bouajila as Félix projects a sense of rounded, considerate, and, as we have seen, emphatically grounded and normalized well-being. Rather than confirming the Lacanian model, I would like to conclude by proposing an interpretation of Drôle de Félix as a

${ }^{3}$ Didier Eribon, Une morale du minoritaire: Variations sur un thème de Jean Genet (Paris: Fayard, "Histoire de la pensée", 2001).

"s Eribon, p. 272.

${ }^{33}$ Malcolm Bowie, Lacan (London: Fontana Press, 1991), p. 109. 
film that proactively addresses the centrality of the law of the father - and then, for reasons not dissimilar to Eribon's critique of Lacan, rejects its contingency in favour of more democratic conceptions of psychic wholeness.

If the problem of "comment devenir père", and its concomitant answer, "by learning from one's own father", are seen as central for Lacan in his formulation of the laws of socialization, then, for Félix, they are to a large extent reversed. Reducing Isabelle's youngest son to tears on two occasions by his incompetence in parenting, and told plainly by Jules that "tu n'es pas mon père", the role of the father is perhaps the relation in which he feels most uneasy. Moreover, in a brief cameo nestled at the chronological heart of Drôle de Félix, he witnesses a mother and her small son meeting another man during a light rail trip. When he is introduced to the fellow passenger, the boy, whose name is also "Félix", asks the man, who we realise is simply an acquaintance of the mother, if he is his father - a question from which the older Félix is largely excluded. Parenthood, given his long-time relationship with another man, and, it might be added, the extent to which even the French left rejected suggestions that the 1999 cohabitation law might open the way to gay adoption, is not at the top of his immediate agenda. To the extent that lesbian and gay access to procreative technologies is met with organized state resistances, homosexuality's defining characteristic in a heteronormative world, its very perversity, remains its exclusion from that other signifying chain - the structure of the nuclear family. Félix's problem, then, in part, is about how to be more than merely incidental without being a father. The answer, he suspects, must surely come from his own father, from whom he has been estranged since birth.

Positioning him as onlooker rather than participant, this second act of witnessing, however, is also one that foregrounds Félix's exclusion from the conventional quest for meaning according to patriarchal values. As such, it serves as a mise en abyme for his projected reunion with his father, but it does so by crossreferencing this with the latent significance of the film's complicating dilemma, his ambiguous response to witnessing the murder. While his inaction over the killing of "un immigrant" culpabilizes him in terms of his legal responsibility, it also does so in terms of a further allegiance. Félix's father, who we are told probably looks a bit like him only darker, has a double significance, at once normative (in his familial function) and contestatory (in his potential to disrupt the modern cosmopolis of contemporary France through racial difference). The dilemma of denouncing the racist murder can be revisited in terms of an internal conflict. Félix wrestles between collusions with normative white French values and his own experiences of otherness, as he interrogates the nexus of paternity, state, authority and race that determines the terrain of his own identity. Edipal resolution, moreover, becomes a mission that has already self-destructed, to the extent that there is a part of his father that may already be dead.

Yet, as the "grand-mère" predicted, the journey's overt end is little more than a pretext. After all, she asks, "What good is a father to someone your age?" 


\section{Murray Pratt}

And when questioned by Daniel about his reunion, Félix avoids the subject by remembering instead the postcards he has promised to send to his new pseudorelations. Although one internet reviewer of Drôle de Félix assures us that Félix does eventually find his father, there is little narrative evidence to suggest that "le père" he meets, despite being the last encounter before arriving in Marseille, has any significance beyond being yet another random stranger who joins the alternative, as opposed to biological family. This is not to say, however, that the middle-aged man fishing by the Rhône with whom Félix stops to talk, largely about what motivates Félix's search for his real father, is irrelevant to a reading of Drôle de Félix as a critique of the Edipal drama. The paternal relation is constructed in terms of a laconic imparting of wisdom and - in as much as the "father" negates most of Félix's assumptions - a laying down of the law in terms of the "Non du père". Rather than offering the key that will unlock the puzzle of his identity, performing symbolically the authority of the Lacanian father, this "père" is presented parodically, exposed to the same relational quirkiness that has marked Félix's previous encounters - one might go so far as to say queered in its contestation of the heteronormative familial structures of the signifying chain. "Solitaire comme des moines", the father figure has effectively renounced his familial duties, recognizing an incongruity with himself that makes him a bad husband and father. So he fishes for no reason other than to fish, or, given the verbal play with the verb "pêcher/pécher", perhaps sins in order to sin, in a river that is polluted anyway.

If Félix finds a father, then it is a father who is inherently fallible rather than the font of all self-knowledge. And, as the conversation between the older and younger man reveals, this is ever the case, as much with biological as with pretended, or symbolic, patriarchs. The search for the father, which has ostensibly motivated Félix's progress, is a story that is neither "très passionnant" nor "très originel", a plotline best left to trashy soap opera. Bringing to mind the Edipal moment of patricide, the alternative father wonders why Félix is looking for his real father at all, and, if it is not to beat him up, advises him to "foutez-lui la paix". Effectively displacing the centrality and primacy of the paternal law as a requirement for successful socialization, the film takes one final detour before reaching its destination. As they drive towards Marseille - a lift offered with the express proviso that it is not to drop Fëlix at his father's - the two men make an unscheduled stop. Patiently teaching the "père" to fly the rainbow kite, which be tells him he can keep, the son both offers instruction and makes a gift to the father, not laying down a law, but providing him with a different perspective.

Having "finished with Lacan once and for all", ${ }^{34}$ Didier Eribon refers to "une résistance gay à la psychanalyse", ${ }^{35}$ one that reveals psychoanalysis's attitude to homosexuality as a disciplinary technology. Tracing a lineage from the

\footnotetext{
${ }^{34}$ The chapters on the homophobic subtext of psychoanalysis are followed by two entitled "Pour en finir avec Jacques Lacan". $\quad{ }^{35}$ Eribon, p. 278.
} 
Gidean reformulation of the psychoanalytical question about "how one becomes a homosexual" as "why it is so difficult to be one", ${ }^{36}$ through Genet's investigation of the ways in which the unconscious incorporates the structures of the social and sexual order, Eribon calls for "une politique de la décolonisation de l'esprit"37 such as he finds in the latter's writings, one that undoes the conceptual sequencing of Fdipal thinking through a reinvention of the gay self characterized by "nouvelles formes de subjectivités, construites individuellement et collectivement" ${ }^{38}$ Conjoining Genet with Patrick Chamoiseau's critique of colonial domination, Eribon sees the decolonization of the self as a work that would "défaire [la domination] en chantant 'l'indicible', en veillant 'à augmenter l'imprévisible' afin d'assurer 'la déroute des inerties psychiques'." "La lutte", he continues, "peut n'être pas 'spectaculaire', nous prévient [Chamoiseau]: elle peut sembler limitée à de modestes contributions, par le moyen des livres, de gestes partiels ou inaboutis, de déplacements à peine perceptibles. Mais les effets en sont profonds." 39

The light-hearted quirkiness of Félix's journey, then, as understood by the film's reviewers in their reluctance to ascribe meaningfulness, or full meaning, to Drôle de Félix, can be understood as, at least in part, an appropriate response to the meandering and unspectacular detours of a work akin to the self-decolonization described by Chamoiseau and recontextualized as a form of queer counteridentification by Eribon. In his unspectacular, partial and incomplete remapping of a social landscape, Félix begins to take a road less travelled, reconstructing a sense of identity coloured differently from the subjugated and shamed positions that routinely disempower homosexuals, racial minorities, people living with HIV and AIDS. Resembling the hardly noticeable displacements characterising the struggle against colonial domination, Félix's cinematically uncomplicated search for value in the everyday can best be understood against the shadow negotiations with the lived effects of racism, homophobia and prejudice against AIDS, factors that complicate a sense of home and belonging for many of those who have to deal with them in a less utopic universe, including, no doubt, many of the film's affirmative reviewers. In a French context, Drôle de Félix gently dislodges the national script of undifferentiated citizenship as it charts ways of communing that bypass the normative assumptions of this spurious myth. The journey is perhaps never quite as easy, or quite as direct, as it appears, and in its deep effects, as Félix teaches himself to "forget his doubts and follow his own path" in the words of the song he sings to himself, the film is one brief lesson in how homosexuality, racial difference and living with HIV can be imagined as something more than inconsequentiality.

University of Technology, Sydney

${ }^{36}$ Eribon, p. $282 . \quad{ }^{37}$ Eribon, p. $295 . \quad{ }^{38}$ Eribon, p. $294 . \quad{ }^{39}$ Eribon, p. 294. 